\title{
The Expression Levels of MicroRNA-31, MicroRNA-125a and MicroRNA-125b in Chronic Rhinosinusitis with Nasal Polyp
}

\section{Nazal Polipli Kronik Sinüzitte MikroRNA-31, MikroRNA-125a ve MikroRNA-125b Seviyeleri}

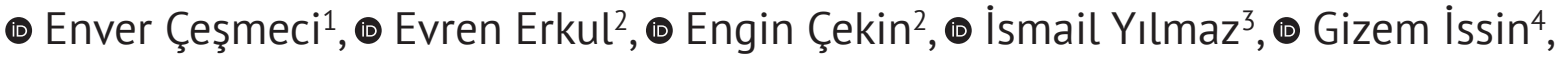 \\ ๑ Atila Güngör ${ }^{5}, \oplus$ Ersin Tural ${ }^{6}$ \\ ${ }^{1}$ Gölcük State Hospital, Clinic of Otolaryngology, Kocaeli, Turkey \\ ${ }^{2}$ University of Health Sciences Turkey, İstanbul Sultan 2. Abdülhamid Han Training and Research Hospital, Clinic of Otolaryngology, Istanbul, Turkey \\ ${ }^{3}$ University of Health Sciences Turkey, İstanbul Sultan 2. Abdülhamid Han Training and Research Hospital, Clinic of Pathology, Istanbul, Turkey \\ ${ }^{4}$ Binali Yıldırım University Faculty of Medicine, Mengücek Gazi Training and Research Hospital, Clinic of Pathology, Erzincan, Turkey \\ ${ }^{5}$ Istanbul Göztepe Medical Park Hospital, Clinic of Otolaryngology, İstanbul, Turkey \\ ${ }^{6}$ University of Health Sciences Turkey, Istanbul Sultan 2. Abdülhamid Han Training and Research Hospital, Clinic of Pediatrics, Istanbul, Turkey
}

Background: Nasal polyposis is a disease with chronic inflammation of the sinonasal mucosa. Expression of micro-RNAs is altered in many diseases. The goal of this study is to evaluate the expression levels of inflammation associated micro-RNAs in chronic rhinosinusitis with nasal polyposis and to show the correlation between nasal polyps and micro-RNAs.

Materials and Methods: This retrospective study was designed in patients who underwent endoscopic sinus surgery between January 2006 and June 2015. One hundred and ten patients who underwent endoscopic sinus surgery in our clinic were included in the study. Micro-RNA31, micro-RNA125a, and micro-RNA125b were evaluated using real time quantitative reverse transcription polymerase chain reaction in adjacent normal nasal mucosa of nasal polyp and nasal polyp samples of the patients with chronic rhinosinusitis with nasal polyposis.

Results: Only 40 patients met the inclusion criteria. The mean micro-RNA levels of micro-RNA-125b, micro-RNA-125a, and microRNA-31were found to be elevated in nasal polyp tissues compared to adjacent normal nasal mucosa, but there was no statistically significant difference in the expression levels of miRNA-125b, miRNA-31 and miRNA-125a between normal tissue and nasal polyp. Conclusion: We could not find any results indicating that miRNA-125b. miRNA31 and miRNA-125a would be effective in the pathogenesis of nasal polyp.

Keywords: MicroRNA, chronic rhinosinusitis, nasal polyp, inflammation

Amaç: Kronik sinüzite eşlik eden nazal polipozis sinonazal mukozanın enflamasyonu ile karakterize bir sendromdur. MikroRNA’ların düzensiz ifadesi birçok hastalıkta gösterilmiştir. Amacımız kronik sinüzite eşlik eden nazal polipozis hastalarında üç farklı mikroRNA’nın ekspresyon düzeylerini değerlendirmek ve mikroRNA’lar ile nazal polipozis arasındaki ilişkiyi araştırmaktır.

Gereç ve Yöntemler: Çalışma retrospektif olarak yürütüldü ve Ocak 2006-Haziran 2015 tarihleri arasında kronik sinüzite eşlik eden nazal polipozis nedeniyle endoskopik sinüs cerrahisi uygulanan 110 hasta çalışmaya dahil edildi. Bu hastaların nazal polip dokuları ve bitişiğindeki sağlam nazal mukoza dokularında enflamasyon ile yakından ilgili olduğu bilinen üç farklı mikroRNA (mikroRNA31, mikroRNA125a, mikroRNA125b) düzeyleri gerçek zamanlı kantitatif revers transkripsiyon polimeraz zincir reaksiyonu kullanılarak analiz edildi.

Bulgular: Çalışmaya dahil edilen 110 hasta arasından sadece 40 hasta bu çalışma için uygun bulundu. mikroRNA-31, mikroRNA -125a ve mikroRNA-125b’nin ortalama mikroRNA seviyelerinin, normal nazal mukozaya kıyasla nazal polip dokularında arttığı bulundu, ancak fark istatiksel olarak anlamlı değildi.

Sonuç: Kronik sinüzite eşik eden nazal polipozis patgogenezinde mikroRNA-31, mikroRNA-125a ve mikroRNA-125b'nin etkili olabileceğini gösteren herhangi bir sonuç bulunmadı.

Anahtar Kelimeler: MikroRNA, kronik sinüzit, nazal polip, enflamasyon

Address for Correspondence: Enver Çeşmeci, Gölcük State Hospital, Clinic of Otolaryngology, Kocaeli, Turkey

Phone: +90 5957950464 E-mail: envercesmeci@gmail.com ORCID ID: orcid.org/0000-0001-7000-931

Received: 10.11.2020 Accepted: 26.01.2021 


\section{Introduction}

Chronic rhinosinusitis (CRS) is an important disease that severely affects patients' quality of life. It is a sinus disease of nasal cavity and paranasal sinuses in which the sinonasal mucosa is severely and chronically inflamed. CRS is basically divided into two sub-types based on the absence or presence of nasal polyps (NPs): CRS without NPs (CRSsNP) and CRS with NPs (CRSwNP) (1). CRSsNP and CRSwNP have different histologic and immunologic features. Inflammatory cells, particularly B cells and plasma cells are significantly higher in CRSwNP compared to CRSsNP, while the numbers of mucosal glands are higher in CRSsNP compared to CRSwNP $(1,2,3,4,5)$. Tissue remodeling is a part of wound healing and it is a dynamic process involving a structural reconstruction of the tissue (6).

Micro-RNAs (miRNAs) are relatively new defined, small, measuring approximately $\sim 22$ nucleotides in length, noncoding single-stranded RNAs that comprise a new class of gene regulators. miRNAs act primarily as gene expression suppressors $(7,8)$. miRNAs regulate nearly half of the protein-coding genes. These genes bind to the 3' UTR of target mRNA and genes show their effects by inhibition of the translation of target mRNA using degradation or silencing pathways $(9,10,11)$. The first miRNAs (lin- 4 and let-7) were discovered in Caenorhabditis elegans, from that time researcher have reported over 2000 miRNAs in the human genome $(12,13,14)$. Impaired expression of miRNAs has been shown in many diseases, especially in neoplasms and immunologic and inflammatory diseases, for instance allergic asthma, allergic rhinitis, and atopic dermatitis $(7,8)$. Studies on miRNA-31 reveal that it shows different expression levels in different tumors. The miRNA-31 gene is located on chromosome band 9p21.3. It encodes the cell cycle inhibitor proteins $\mathrm{p} 15$ and p16 (15). microRNA-125 family (miRNA-125) consists of miRNA- 125a and miRNA$125 \mathrm{~b}$. They regulate cell differentiation, proliferation, and apoptosis in cells. miRNA-125a and miRNA-125b may lead to diseases such as cancer and autoimmune diseases (14).

The goal of this study is to evaluate the expression levels of three different microRNAs (miRNA31, miRNA125a, miRNA125b) in CRSWNP.

\section{Material and Method}

\section{Patients and Sample Collection}

The study was conducted as a retrospective study. Tissue samples of $40(n=40)$ patients who met the inclusion criteria among 110 patients undergoing endcoscopic sinus surgery between 2006 and 2015 were included in the study.
The patients who underwent endoscopic sinus surgery due to bilateral CRSWNP were included in the study. Ethics committee approval of the study was obtained from of GATA Haydarpaşa Numune Training and Research Hospital (no: 1491-128-13/1539 date: 20/01/2014). Written informed consent was obtained from the patients.

Exclusion criteria included the presence of systemic diseases, fungal sinusitis, congenital mucociliary problems, antrochoanal polyps and cystic fibrosis. Patient characteristics are presented in Table 1.

\section{Selection of miRNAs}

The miRNAs included in the study were determined as a result of the literature review $(11,15,16)$. Three different miRNAs (miRNA31, miRNA125a, miRNA125b) that were associated with inflammation were chosen to investigate their roles in CRSwNP.

\section{Isolation and Relative Quantification of miRNAs}

Macroarray blocks which contained only nasal polyp areas were used for miRNA extraction. Adjacent normal nasal mucosa was used for miRNA extraction to compare miRNA levels. Total RNA isolation and relative quantification was performed using the method described by Livak et al. (17).

\section{Statistical Analysis}

Results were presented as mean \pm standard deviation for continuous variables, and defined as percentages for categorical variables. The $\log _{2}$ transformed fold change data in miRNA-31, miRNA-125a and miRNA-125b expression levels between nasal polyp and normal tissue were analyzed statistically. Statistically significant fold changes in miRNA expression were tested by the inclusion of null value in $95 \%$ confidence interval. E-picos calculator (www.e-picos.com) was used for statistical analysis.

\section{Results}

A total of 40 patients were studied among 110 patients. The mean age of the patients was 42.1 years. Thirty one of the patients were male and 9 were female. The mean miRNA expression levels of nasal polyp tissues normalized to normal tissues are presented in Table 2 . The mean miRNA

\section{Table 1. Baseline characteristics of the patients}

\begin{tabular}{|l|l|}
\hline Patients, $\mathrm{n}$ & 40 \\
\hline Mean age (range), years & $42.1(20-87)$ \\
\hline Females/males, $\mathrm{n}$ & $9 / 31$ \\
\hline History of allergic rhinitis & 8 \\
\hline History of allergic asthma & 1 \\
\hline Previous sinus surgeries, yes/no & $15 / 25$ \\
\hline
\end{tabular}


levels of miRNA-31, miRNA-125a, and miRNA-125b were found to be increased in nasal polyp tissues compared to normal nasal mucosa. The mean miRNA levels of miRNA-31, miRNA-125a, and miRNA-125b were 1,698 fold, 2,797 fold, and 1,423 fold, respectively. Using transformed data, the presence of a statistically significant difference in miRNA expression levels between nasal polyp and normal tissue was tested with confidence interval detection (Table 3). There was no statistically significant difference in the expression levels of miRNA-31, miRNA-125a and miRNA$125 \mathrm{~b}$ in nasal polyp tissue compared to normal tissue. Bootstrap analysis was performed to eliminate an error due to an insufficient sample size for miRNA-125a data that did not conform to the normal distribution (Table 4). There were no different results after Bootstrap analysis.

Table 2. Comparison of the mean micro RNA (miRNA) expression levels in nasal polyp tissue

\begin{tabular}{|l|l|}
\hline & 95\% confidence interval \\
\hline miRNA-31 & Mean miRNA expression change (fold) \\
\hline miRNA-125a & 1.698 \\
\hline miRNA-125b & 2.797 \\
\hline
\end{tabular}

Table 3. Fold change ( $\log _{2}$ transformed) miRNA-31, miRNA-125a, miRNA-125b expression levels

\begin{tabular}{|l|l|l|l|}
\hline & & \multicolumn{2}{|c|}{ 95\% confidence interval } \\
\hline & Mean & Minimum & Maximum \\
\hline miRNA-31 & -0.2215 & -0.7752 & 0.3321 \\
\hline miRNA-125a & 0.5263 & -0.1602 & 1.2127 \\
\hline miRNA-125b & -0.3183 & -0.9142 & 0.2777 \\
\hline
\end{tabular}

Table 4. Fold change ( $\log _{2}$ transformed) miRNA-31, miRNA125a, miRNA-125b expression levels after Bootsrap analysis using Statkey

\begin{tabular}{|l|l|l|l|}
\hline & & \multicolumn{2}{|c|}{ 95\% confidence interval } \\
\hline & Mean & Minimum & Maximum \\
\hline miRNA-31 & -0.2197 & -0.7488 & 0.3135 \\
\hline miRNA-125a & 0.5232 & -0.1623 & 1.1409 \\
\hline miRNA-125b & -0.3183 & -0.9025 & 0.2411 \\
\hline
\end{tabular}

\section{Discussion}

Chronic inflammation such as allergic rhinitis and CRS cause tissue remodeling in upper airways. CRSwNP progresses with benign edematous polyp formation and sinonasal mucosal thickening. Eosinophil infiltration, chronic mononuclear cells, and epithelial goblet cell hyperplasia are seen in histopathological examinations.
An increase in basement membrane, in $\alpha$-smooth muscle actin ( $\alpha$-SMA), myofibroblasts and submucosal collagen deposition is associated with upper airway remodeling $(11,18,19)$. The etiology of CRS remains to be unknown and CRS etiopathogenesis and its inflammation mechanism is still not well defined. miRNAs are small, 22-nucleotide RNAs. miRNAs control different variety of targeted genes which affect translation and stability of mRNA. Recent researches have shown that miRNAs play very important roles in a wide variety of biological processes for instance in proliferation, differentiation, apoptosis, signal transduction and organ development (12). There are studies aiming to investigate the roles of miRNAs in CRS etiology. Zhang et al. (5) researched the expression levels of miRNA machinery proteins in CRSwNP, CRSsNP and control groups. They found that protein activator of the interferon-induced protein kinase (PACT) mRNA expression was found to be impaired in CRS and PACT was upregulated in CRSwNP as compared to the controls and CRSsNP. Zhang et al. (16) evaluated the expression levels of miRNA-125b in CRSwNPand CRSsNPand reported miRNA-125b was upregulated in CRSwNP. There was no statistically significant difference in the expression levels of miRNA-125b in nasal polyp tissue compared to normal tissue in our study. There may be several reasons for the discrepancy between the two studies. First, Zhang et al. (16) divided CRSwNP cases into eosinophilic and noneosinophilic cases and found miRNA-125b expression levels higher in eosinophilic CRSwNP cases. We did not divide the CRSwNP cases into two, and this may be one of the reasons for the discrepancy between the two studies. In our study, we compared miRNA levels with nasal polyp tissue and adjacent healthy nasal mucosa in CRSwNP patients. Zhang et al. (16) compared nasal polyp tissue of CRSwP cases and inferior turbinate mucosa of control patients who underwent septoplasty operation. We thought it would be more accurate to compare the miRNA levels in nasal polyp tissue with the adjacent healthy tissue of the same patient. Xia et al. (20) compared expression levels of miRNA-125b and other six miRNAs (miRNA-181b, miRNA-26b, miRNA-155, miRNA-146a, miRNA-, miR-124 and miRNA-92a) in nasal polyp tissue in CRS patients and in nasal mucosa of control patients. They reported miRNA-125b, miRNA-155 and miRNA-146a were up-regulated while miRNA-92a, miRNA$26 \mathrm{~b}$ and miRNA-181b were down-regulated. There was no study investigating miRNA-31 levels in nasal polyp tissue so far in our literature review. Xia et al. (20) reported miRNA 124 expression levels were not found to have significant changes while Liu et al. (21) reported significantly decreased expression levels of miRNA 124 in nasal polyp tissue. Yu et al. (22) investigated miRNA-663 expression levels in nasal polyp tissue in pediatric population and reported miR-663 
expression was significantly decreased in nasal polyp tissue. Luo et al. (23) reported increased expression levels of miRNA19a in nasal polyp tissue. Li X et al. (11) reported significantly increased levels of miRNA-21 in CRSwNP than those in CRSsNP and controls. There may be several reasons for the discrepancy between our study and the literature. The low number of samples may be one of these reasons. There are no accepted normal ranges for miRNA levels yet. Therefore, in our study, we used the histopathologically normal healthy nasal mucosa adjacent to the nasal polyp tissue of the same patient in order to compare miRNA levels. In other studies in the literature, healthy nasal mucosa of patients without NPs was used to compare the levels of miRNA in nasal polyp tissue of patients with chronic sinusitis. Researchers who designed a study in this way may have considered the nasal mucosa as a single unit and thought that there was no difference between the polyp developing part of the nasal mucosa and the non-developing part in terms of many parameters including miRNA levels. However, in our opinion, the most important weakness of the studies conducted in this way is that there is no accepted normalized value for a certain region of the human body for each miRNAs. Therefore, we think that comparing miRNA levels obtained from nasal polyp tissue of CRSWNP patients with miRNa levels obtained from normal nasal mucosa of healthy individuals is not very reliable.

\section{Conclusion}

We could not find any results indicating that miRNA31, miRNA-125a and miRNA-125b would be effective in the pathogenesis of nasal polyp. This result may be due to the fact that we used the same patient's intact nasal mucosa to compare miRNA levels, unlike the literature. A consensus is needed on the comparison of miRNA levels. Studies with larger patient numbers based on this consensus will clarify the role of miRNA levels in nasal polyp pathogenesis.

\section{Ethics}

Ethics Committee Approval: Ethics Committee Approval of the study was obtained from of GATA Haydarpaşa Training and Research Hospital (number: 1491-128-13/1539 date: 20/01/2014).

Informed Consent: Written informed consent was obtained from the patients.

Peer-review: Internally peer-reviewed.

\section{Authorship Contributions}

Surgical and Medical Practices: E.Ç., E.E., E.ÇEK., A.G., Concept: E.Ç., E.E., E.ÇEK., I.Y., G.I., A.G., Design: E.Ç., E.E., E.ÇEK., I.Y., G.I., A.G., E.T., Data Collection or Processing: E.Ç.,
I.Y., G.I., E.T., Analysis or Interpretation: E.T., I.Y., E.T., Literature Search: E.Ç., E.T., Writing: E.Ç., E.E., E.T.

Conflict of Interest: No conflict of interest was declared by the authors.

Financial Disclosure: The authors declared that this study received no financial support.

\section{References}

1. Fokkens WJ, Lund VJ, Mullol J, Bachert C, Alobid I, Baroody F, et al. EPOS 2012: European position paper on rhinosinusitis and nasal polyps 2012. A summary for otorhinolaryngologists. Rhinology. 2012;50:1-12. [Crossref]

2. Cao PP, Li HB, Wang BF, Wang SB, You XJ, Cui YH, et al. Distinct immunopathologic characteristics of various types of chronic rhinosinusitis in adult Chinese.J Allergy Clin Immunol. 2009;124:478-484. [Crossref]

3. Polzehl D, Moeller P, Riechelmann H, Perner S. Distinct features of chronic rhinosinusitis with and without nasal polyps. Allergy. 2006;61:1275-1279. [Crossref]

4. Van Zele T, Claeys S, Gevaert P,Van Maele G, Holtappels G,Van Cauwenberge $P$, et al. Differentiation of chronic sinus diseases by measurement of inflammatory mediators. Allergy. 2006;61:1280-1289. [Crossref]

5. Zhang YN, Cao PP,Zhang XH, Lu X, Liu Z. Expression of microRNA machinery proteins in different types of chronic rhinosinusitis. Laryngoscope. 2012;122:2621-2627. [Crossref]

6. Van Bruaene N, Bachert C. Tissue remodeling in chronic rhinosinusitis. Curr Opin Allergy Clin Immunol. 2011;11:8-11. [Crossref]

7. Bader AG, Brown D, Winkler M. The promise of microRNA replacement therapy. Cancer Res. 2010;70:7027-7030. [Crossref]

8. Bartel DP. MicroRNAs: genomics, biogenesis, mechanism, and function. Cell. 2004;116:281-297. [Crossref]

9. Ambros V. The evolution of our thinking about microRNAs. Nat Med. 2008;14:1036-1040. [Crossref]

10. Friedman RC, Farh KK, Burge CB, Bartel DP. Most mammalian mRNAs are conserved targets of microRNAs. Genome Res. 2009;19:92-105. [Crossref]

11. Li X, Li C, Zhu G, Yuan W, Xiao ZA. TGF- $\beta 1$ Induces Epithelial-Mesenchymal Transition of Chronic Sinusitis with Nasal Polyps through MicroRNA-21. Int Arch Allergy Immunol. 2019;179:304-319. [Crossref]

12. Lee RC, Feinbaum RL,Ambros V. The Caenorhabditis elegans heterochronic gene lin-4 encodes small RNAs with antisense complementarity to lin-14. Cell. 1993;75:843-854. [Crossref]

13. Reinhart BJ, Slack FJ, Basson M, Pasquinelli AE, Bettinger JC, Rougvie AE, et al. The 21-nucleotide let-7 RNA regulates developmental timing in Caenorhabditis elegans. Nature. 2000;403:901-906. [Crossref]

14. Wang JK, Wang Z, Li G. MicroRNA-125 in immunity and cancer. Cancer Lett. 2019;454:134-145. [Crossref]

15. Laurila EM, Kallioniemi A. The diverse role of miR-31 in regulating cancer associated phenotypes. Genes Chromosomes Cancer. 2013;52:1103-1113. [Crossref]

16. Zhang XH, Zhang YN, Li HB, Hu CY, Wang N, Cao PP, et al. Overexpression of miR-125b, a novel regulator of innate immunity, in eosinophilic chronic rhinosinusitis with nasal polyps. Am J Respir Crit Care Med. 2012;185:140151. [Crossref]

17. Livak KJ, Schmittgen TD. Analysis of relative gene expression data using real-time quantitative PCR and the 2(-Delta Delta C(T)) Method. Methods. 2001;25:402-408. [Crossref]

18. Molet SM, Hamid QA, Hamilos DL. IL-11 and IL-17 expression in nasal polyps: relationship to collagen deposition and suppression by intranasal fluticasone propionate. Laryngoscope. 2003;113:1803-1812. [Crossref] 
19. Serpero L, Petecchia L, Sabatini F, Giuliani M, Silvestri M, Di Blasi P, et al. The effect of transforming growth factor (TGF)-beta1 and (TGF)-beta2 on nasal polyp fibroblast activities involved upper airway remodeling: modulation by fluticasone propionate. Immunol Lett. 2006;105:61-67. [Crossref]

20. Xia G, Bao L, Gao W, Liu S, Ji K, Li J. Differentially expressed mirna in inflammatory mucosa of chronic rhinosinusitis. J Nanosci Nanotechnol. 2015;15:2132-2139. [Crossref]

21. Liu CC,Xia M,Zhang YJ,Jin P,Zhao L,Zhang J, et al. Micro124-mediated AHR expression regulates the inflammatory response of chronic rhinosinusitis
(CRS) with nasal polyps. Biochem Biophys Res Commun. 2018;500:145151. [Crossref]

22. Yu H, Ju J, Liu J, Li D. Aberrant expression of miR-663 and transforming growth factor- $\beta 1$ in nasal polyposis in children. Exp Ther Med. 2018;15:4550-4556. [Crossref]

23. Luo XQ, Shao JB, Xie RD, Zeng L, Li XX, Qiu SO, et al. Micro RNA-19a interferes with IL-10 expression in peripheral dendritic cells of patients with nasal polyposis. Oncotarget. 2017;8:48915-48921. [Crossref] 